\title{
Mythological Names and dróttkvætt Formulae II: Base-Word-Determinant Indexing
}

Frog*

\begin{abstract}
This article explores patterns of language use in oral poetry within a variety of semantic formula. Such a formula may vary its surface texture in relation to phonic demands of the metrical environment in which it is realised. This is the second part of a four-part series based on metrically entangled kennings in Old Norse dróttkvoett poetry as primary material. Old Norse kennings present a semantic formula of a particular type which is valuable as an example owing to the extremes of textural variation that it enables. The first part in this series introduced the approach to kennings as semantic formulae and included an illustrative case study on kennings meaning 'battle' realising the last three metrical positions of a dróttkvoett line. This demonstrated that lexical variation in realising these formulae varied according to functional equivalence across semantic categories. The present case study advances this discussion through the examination of the metrical entanglement of the lexicon in realising the semantic formula. On the one hand, it presents evidence of the associative indexing of lexical items realising a battle-kenning of this particular metric-structural type: certain kenning base-words exhibit a preferred semantic category of determinant. On the other hand, it also presents evidence of the associative indexing of lexical items that are used for realising the metrically required rhyme in a position in the line that is outside of the semantic formula: certain kenning base-words exhibit co-occurrence with a particular rhyme-word.
\end{abstract}

Keywords: oral poetry, variation, formula, skaldic poetry, dróttkvœett, kenning

This is the second part of a four-part discussion that addresses a phenomenon that I describe as the 'metrical entanglement' of language in an oral-poetic tradition, looking particularly at verbal variation in semantic formulae. This phenomenon is addressed through semantic formulae of a particular type called a kenning in Old Norse skaldic poetry. The article builds on a pilot study of 340 examples of kennings meaning 'battle' in the metre known as dróttkvott (Frog forthcoming). The four-part discussion explores phenomena revealed by

* Author's address: Frog, Folklore Studies / Department of Philosophy, History, Culture and Art Studies, University of Helsinki, P.O. Box 59 (Unioninkatu 38 A), 00014 University of Helsinki, Finland. E-mail: mr.frog@helsinki.fi. 
the pilot study in greater detail through a series of three case studies of different metric-structural basic types, which will be followed by a final synthesis and discussion. The data-set for each case study has been considerably expanded from that of the pilot study, although it should not be considered exhaustive. Particular attention is given to variation between the use of nouns referring to weapons and armour (implements of battle) versus names of valkyries and of the god Odin (mythological agents of battle) in realising the metrically entangled battle-kenning formulae. This attention is both owing to the unambiguous difference between these as semantic categories as well as a concern for the degree to which the vocabulary of proper names was fully integrated into the poetic register and into the strategies for poetic composition.

The first article in this series (Frog 2014a) presented the register-based approach to oral poetry employed here as well as the framework for approaching kennings as semantic formulae. It also introduced the metrical entanglement of semantic formulae in the case of kennings through basic type 12(p)XYy and provided an initial demonstration of the integration of personal names into the registral lexicon of dróttkveett poetry. The present case study turns to the more frequently attested basic type 1(p)YyXx discussed in a dataset of 80 examples. Focus in this case study is on evidence that certain words used in realising a metrically entangled formula may exhibit $a$ ) preferred categories of equivalent lexical items for completing the formula as well as $b$ ) conventionally associated verbal material for completing the metrical line. In order to improve the general accessibility of this article, the case study is prefaced with a brief review of the background, terms and approach employed so that it is possible to follow the argument and discussion without referring back to the first article in this series.

\section{Background and Terms}

Metrical entanglement is here used to describe the phenomenon by which the language of an oral-poetic system becomes bound up with metrical positions or other metrical parameters. Metrical entanglement occurs along a continuum, on which degrees of fixity are described in terms of crystallisation, ${ }^{1}$ at the extreme of which is 'metrical boundedness' with the potential for the 'fossilisation' of lexical material. Metrical boundedness was a qualifying feature of Milman Parry's early definition of the formula in oral poetry as "an expression which is regularly used, under the same metrical conditions, to express

1 Following Siikala 1990 [1984]; on the choice of this term, see also Frog 2014a: 103n.6. 
a particular essential idea" (Parry 1928: 16, emphasis added), a definition later propagated by his student Albert Lord (1960: 4). Such prefabricated formulaic expressions have thus received tremendous attention with the rise of Oral-Formulaic Theory. ${ }^{2}$ The metrical boundedness of such formulae has sometimes been exaggerated, and Parry's advocation of metrical fixity in defining a formula (circularly derived from his statistical method for identifying formulaic language) proved too narrow for general use (e.g. Hainsworth 1968). A formulaic expression is approached here as a general linguistic phenomenon that may also take shape in the metrical environment of oral poetry. Following Alison Wray (2009: 28-34), a linguistic formula is here defined in terms of morpheme-equivalence: it is characterised by a coherent unit of meaning with an exclusive entry in the mental lexicon of language users, even if it can be analysed and appropriately interpreted according to rules of the grammar (cf. Parry's "particular essential idea"; cf. also the discussion of emic conceptions of a 'word' in an oral-poetic register in Foley 1999: 67-69 and the definition of an oral-poetic formula "as an integer of traditional meaning" in Foley \& Ramey 2012: 80). This will provide a frame for considering metrically entangled kennings as semantic formulae exhibiting variation at the lexical surface of the text.

The present investigation is developed on a usage-based approach to language and variation, according to which individuals internalise language and the strategies and associations of conventional language usages through exposure to and participation in cultural practices. This approach is developed through register theory (e.g. Halliday 1978; Foley 1995; Agha 2007). Following register theory, language does not function in social practice as a monolithic ideal abstraction - la langue of Saussure (1967 [1916]) - but instead is constituted of and internalised through multitudinous varieties and sub-varieties

2 On Oral-Formulaic Theory and the formula, see e.g. the reviews in Foley 1988 and Foley \& Ramey 2011; cf. also its relation to other approaches to oral and performative expression in Foley 1995. Scholars of skaldic poetry who are less familiar with Oral-Formulaic Theory or think of it solely in terms of Albert Lord's Singer of Tales (1960) may find this frame of reference incongruous. However, Oral-Formulaic Theory has developed considerably across the past half-century. 'Composition in performance' and 'memorisation' have not been regarded as mutually exclusive opposites for a long time. Questions of how the resources of a tradition relate to the entextualisation of e.g. a narrative or communication are complementary to questions of how the same resources may function as mnemonics for producing similar expressions (e.g. 'themes') or for reproducing socially recognisable texts. Within this frame, resources of the skaldic register are used for the entextualisation of utterances (whether that process is slow and reflective or in the situation of performance, as in insult exchanges) that become socially circulating texts, and fluency in the resources of the idiom must have reciprocally provided the mental equipment necessary to remember and reproduce those socially circulating texts. 
linked with situations, contexts, users and uses. The term register is a flexible tool used to designate such varieties. This term can be calibrated in relation to the research object. When applied to an oral poetry tradition, the linguistic register is the historically developed and metrically conditioned language as used in that poetry, ranging from its lexicon and semantics to grammar, phonology and patterns of use. Thus, whereas modern poetry can and does draw on the full spectrum of linguistic resources available and can produce meanings in relation to them (cf. Hasan 1989: 90-106) - i.e. all registers are potentially open to it - an oral-poetic tradition will be characterised by its own register and meanings are produced in relation to that framework of linguistic behaviour (cf. Foley 1995; 1999: 65-88). Novelty that significantly deviates from that framework therefore becomes unlikely insofar as it may threaten the success and effectiveness of communication (Abrahams 1969: 194; cf. Foley 1991). Within the register of Old Norse skaldic (and related) poetry, the present discussion will be particularly concerned with the register (or sub-register) of dróttkveett poetry. In this tradition, calibrating register in relation to a metre is relevant because the broader register of skaldic (and related) poetry was conventionally applied across a number of metres. This broader register was thus metrically entangled with each of those metres, especially in relation to their relevant metrical requirements. In other words, within the register, formulae and similar resources also took shape in relation to individual metres and their particular conventions. Insofar as the metres were different, dróttkveett had, for example, a distinctive and extensive lexicon of formulae interfaced with the metre and that functioned as resources for composition in that metre but not necessarily in others (see further Frog 2014a: 107-109). Thus, addressing a 'register' of dróttkvoett calibrates focus onto linguistic resources that are metrically entangled with that particular metre. Here, focus will be more specifically on the metrical entanglement of battle-kennings as semantic formulae in dróttkvoett expression.

The dróttkvoett metre was essentially syllabic (with rule-governed flexibility) composed in couplets, with two couplets forming a half-stanza called a helmingr. Rules of syntax allowed a remarkable scrambling of language through a helmingr, and two (rarely more) clauses or independent statements could be interwoven across those four lines. The main conventional constraints relevant to the present discussion are rhyme and alliteration; syllable weight, relevant to the first and third case studies in this series, need not be discussed here. Two lexically stressed syllables in odd lines should alliterate with the first stressed syllable in the following even line of a couplet. Rhyme was more variable in practice, but normally the penultimate syllable (but not the following inflectional ending) of each line should rhyme with a preceding syllable; in odd lines, this should be skothending rhyme, not including the vowel (e.g. 
1b.i below: Gunnr um geira sennu); in even lines, this should be aðalhending rhyme, including the vowel (e.g. 1a.i below: menn at vápna sennu). ${ }^{3}$

A kenning is a rhetorical figure that forms a Noun Phrase (NP). In most registers (poetic or otherwise), kennings are for the most part crystallised formulaic expressions or have become wholly lexicalised, fossilised and idiomatic. This rhetorical figure is formed of a noun called a base-word $\left(\mathrm{NP}_{1}\right)$ complemented by a second noun called a determinant $\left(\mathrm{NP}_{2}\right)$ in the genitive case or by forming a compound, and these together signify a third, nominal referent (thus: $\mathrm{NP}_{2}$-GEN NP${ }_{1}$ or $\mathrm{NP}_{2}-\mathrm{NP}_{1}=\mathrm{NP}_{3}$ when $\mathrm{NP}_{3} \neq \mathrm{NP}_{1}$ or $\mathrm{NP}_{2}$ ). For example, the base-word $h r i d$ = 'storm' can be complimented by the determinant sver $ð=$ 'sword' to form a battle-kenning in the following ways: hrí sverðs = 'storm of the sword', hrí sverða = 'storm of swords' or sverðhrí = 'swordstorm. Kennings in skaldic poetry are exceptional because they functioned generatively: the register was characterised by a rich lexicon of semantically equivalent terms called heiti (sg. also heiti) which could be interchangeable in realising a particular kenning as a semantic unit according to "paradigmatic substitution" (Clunies Ross et al. 2012: 1xxi). Thus in the above example, hri is a weather-heiti interchangeable with él = 'squall', drifa = 'snowstorm', $h r e g g=$ 'rainstorm', regn = 'rain', skúr = 'shower', veðr = 'weather; wind', etc. At the same time, sverd can vary with other sword-heiti, and also within a broader equivalence class with other weapon-heiti, and still more generally with heiti for implements of battle. This potential for substitution between individual heiti is only within a two-element kenning, which can be called a basic kenning or a simple kenning. To complicate matters, especially the NP of the determinant could be realised through another kenning, and the determinant NP of that kenning could be realised through yet another kenning, and so on, turning the basic kenning into a complex kenning (i.e. [ $\left[\mathrm{NP}_{n}-\mathrm{GEN} \mathrm{NP}_{3}\right]$-GEN NP$\left.{ }_{2}\right]$-GEN $\mathrm{NP}_{1}=\mathrm{NP}_{4}$, etc.). This generative system for kennings and rich vocabulary of heiti has enormous potential for lexical variation.

There is a tremendous body of research on kennings, but almost no attention has been given to the relationship between their metrical placement and lexical choice in realising them. The lack of attention to this topic owes in part to the methodological problem of addressing the question (cf. Marold 1983: 43). The identification of metrically entangled kennings as established integers of the register allows these conventional units of composition to provide a frame for assessing lexical choices, which is the focus here. The pilot study (Frog

3 On the dróttkvoett metre, syntax and structuring of stanzas, see further Kuhn 1983: 33-214; Árnason 1991: 81-148; Gade 1995: 1-72; on complexity in skaldic composition, see Wills 2009. 
forthcoming) was developed on the hypothesis that kennings could become entangled with the metre beneath a surface of variation enabled by heiti. In other words, the pilot study set out to test whether a kenning could be "regularly used, under the same metrical conditions, to express a particular essential idea" although, unlike Parry's formulae, the lexical realisation of that kenning could vary according to the phonic/lexical context of the verse in which it was used. Lord (1960: 48-53) observed that a formula could maintain "the same essential meaning and metrical value" although lexical choices for one element of the formula varied according to the "acoustical context" (1960: 53; cf. Foley 1996: 19n.17). He illustrated this with a formula 'to mount a horse', in which a variety of three-syllable poetic terms was used for the component 'horse' (Lord 1960: 48-53). Rather than one element being fixed and the other being in pragmatic variation according to the phonic/lexical environment, the pilot study tested whether both elements of a kenning could exhibit this type of variation.

A test-corpus of battle-kennings was developed and the metrical positions of the words constituting each kenning were mapped within a line or across lines of a half-stanza. Mapping is done by representing each six-position line as a numerical sequence 123456 . Positions filled with a kenning's base-word are replaced with an ' $\mathrm{X}$ ' and those of the determinant with a ' $\mathrm{Y}$ ' (as well as ' $\mathrm{Z}$ ' used to represent the determinant in the determinant kenning) and ' $\mathrm{p}$ ' indicating a preposition (placed in parentheses if optional). Uppercase characters represent the stressed onset syllable and lowercase characters represent unstressed positions. Thus, the line menn at vápna sennu = 'men at a flyting (argument) of weapons' can be mapped 1-at-vápna-sennu, 1p-vápna-Xx, 1(p)YyXx, 12YyXx, etc. Mapping the kennings in this way distinguishes them according to individual metric-structural types described by these codes. This process revealed that more than $70 \%$ of the 340 examples in the test corpus were accounted for by only 10 'basic types. ${ }^{4}$ Rather surprisingly, the majority of battle-kennings in the pilot study seemed potentially based on conventional models.

The first article of the present series discussed examples of the metric-structural basic type 12(p)XYy as a foundation for considering metrically entangled semantic formulae. This metric-structural type was illustrative because the majority of examples exhibited only two base-words which belonged to the same semantic class of heiti (dynr = 'din' and gnýr = 'roar' as terms for 'noise'). ${ }^{5}$

4 Whereas 'complex types' accounted for all elements in complex kennings, these were observed to generally reflect basic types in combination that could be viewed as systematic expansions varying a 'basic type'.

$5 \quad$ E.g. Eiríkr ídyn geira = '...in the din of spears' (HSt Rst 22 ${ }^{\mathrm{I}}$.6); lands folk í gný branda = '... in the roar of brands (swords)' (Ótt Hfl 9'.6). 
Examples with each of these base-words were directly comparable to the formulae discussed by Lord: two elements realised a consistent unit of meaning; one element was stable while the other element varied with a clear connection to realising certain sounds rather than others in the line (especially for rhyme). Unlike the formula described by Lord, the variable element was not limited to a single semantic field. In other words, variation did not remain within a single semantic equivalence class of heiti; the varying element only needed to be a term which could realise the kenning as a unit meaning 'battle'. Dominant models for approaching kennings focus on the semantic categories of kenning constituents and their relationship to one another (e.g. Meissner 1921; Marold 1983: 24-36). This had led to the expectation that semantic categories would provide the basis for formulaic use of kennings in dróttkvoett (Frog, forthcoming). However, as James Fox (1977: 72) has emphasised, formal categorisation and typology based on grouping outcomes of oral-poetic expression do not necessarily render an accurate picture of how language functions and varies in practice (cf. Foley 1999: 66-83). The data supports viewing metrically entangled kennings as established semantic integers of the register - as a variety of formula. On the other hand, variation could not be reduced to synonymsubstitution within a semantic equivalence class. This yields information about paradigmatic substitution in kenning production. When this is observed in the semantic integers of the tradition, it has implications for how language is functioning within that integer in the production of verses. Generally speaking, the primary determinant on lexical choice appears to be pragmatic, based on metrical viability and the phonic/lexical context of the specific verse; the semantic category of the heiti needed only to be viable for forming the battle-kenning. This observation in determinants was paralleled by observing corresponding variation in base-words when additional examples of the basic type were considered. ${ }^{6}$ In other words, the kenning was not formed in a hierarchical process of determining a semantic combination like NOISE of IMPLEMENTS OF BATTLE $\rightarrow$ BATTLE and selecting appropriate heiti; the semantic integer BATTLE was the basis and the specific semantic combination forming the kenning was an outcome of pragmatic variation according to the context. In the generative production of kennings, this suggests that lexical choice did not necessarily require reflection on the specific semantic category of heiti. A poet fluent in the idiom could complete this unit on the basis of phonic needs (e.g. rhyme or alliteration) without having to reflect on whether the determinant

6 In basic type 12(p)XYy battle-kennings, this was particularly apparent because base-words other than dynr and gnýr were found almost exclusively where the base-word was required to carry alliteration. 
was a valkyrie-heiti or a spear-heiti. ${ }^{7}$ In other words, this unit BATTLE could be used in composition "without recourse to any form-meaning matching of any sub-parts it may have" (Wray 2008: 12).

Poetic equivalence vocabulary, as in an equivalence class of heiti, may be compared to synonymy in aesthetically unmarked discourse. A crucial difference is that this equivalence vocabulary develops to enable pragmatic variation according to the phonetic and lexical environment of poetic expression. As a historical process, oral-poetic registers develop a lexicon to 'say the same thing' within different verse contexts (e.g. meeting $h$-alliteration, a particular syllabic structure or avoiding lexical repetition in parallelism). In some cases, this may be constituted of alternative historical or dialectal forms that have produced phonological allomorphs, ${ }^{8}$ as well as parallel inflections as allomorphs. ${ }^{9}$ In other cases, words from other dialects or other languages are assimilated as poetic equivalents (Foley 1996: 27-37; Fox 2014: 374-383) and words from other contexts may have their semantics 'bent' or 'stretched' to conform to the needs of the poetic register (Roper 2012).$^{10}$ Within poetic discourse, many of these exhibit the potential to function as suppletive allomorphs (cf. English go / went; good / better). Whereas allomorph variation in aesthetically unmarked discourse tends to be conditioned by adjacent sounds (especially phonological allomorphs) and grammatical contexts, allomorphy in poetic discourse is further conditioned by broader phonological, lexical and metrical environments. Where variation can be observed between lexical items within conventionalised poetic structures, this offers information about categories and degrees of equivalence (cf. Jakobson 1987 [1956]: 111). From this perspective, the different three-syllable words for horse in the formula 'to mount a horse' described by Lord can be viewed as allomorphs in variation insofar as alternation between terms is dependent on contextual factors. Although it cannot be assumed that all heiti of a semantic equivalence class functioned as allomorphs or that they did so in all contexts, metrically entangled kennings suggest that, within these formulae, appropriate heiti were employed

\footnotetext{
7 Competent users of a poetic register can be expected to work within a metre to some degree unconsciously as a function of internalising the register with its strategies and solutions for producing metrically well-formed expressions. It is common that skilled performers cannot articulate such processes better than, for example, simply saying "that the words draw one another up that way" (Lönnrot 1845: 36).

8 Cf. Latin egŏ / egō = 'I' etc. based on historical change (Coleman 1999: 37-38); South Slavic dète $/$ dijete $=$ 'child' etc. as alternative dialectal forms (Foley 1996: 28).

9 Cf. Latin variants of the third person plural perfect -êre, -ěrunt and -èrunt (Coleman 1999: 44); Old Norse parallel genitive forms in Ygg-s and Ygg-jar = 'Odin-GEN'.

10 Cf. Middle English tolk = lit. 'translator', poetic 'man' for $t$-alliteration (Roper 2012: 89).
} 
as suppletive allomorphs that were characterised by semantic function within the rhetorical figure rather than by their individual semantic value (i.e. $\mathrm{NP}_{1}=$ [battle-kenning base-word]; $\mathrm{NP}_{2}=$ [battle-kenning determinant]). Such a kenning can be described as a semantic formula: a morpheme-equivalent integer of the register in which both elements can be functional allomorphs. As formulae, such kennings had potential to be produced and interpreted without reflection and analysis by individuals fluent in the idiom: the use/recognition of appropriate elements (heiti) in appropriate metrical positions could itself enable the apprehension of the referent without necessarily requiring the literal interpretation of elements and parsing their relation. ${ }^{11}$ From this model of a semantic formula, basic type 1(p)YyXx can be addressed to look at the entanglement of the lexicon in realising a semantic formula of this type.

\section{Basic Type 1(p)YyXx}

Battle kennings of basic type 1(p)YyXx are presented here in 80 examples (noting that the complexity of skaldic verses inevitably leaves some examples open to alternative interpretations). Examples listed below exclude cases of extended battle-kennings in variations on the basic type. Examples in which an adjective complemented the kenning without otherwise impacting its semantics or the metrical distribution of the determinant and the base-word are included without special indication. ${ }^{12}$ In this basic type, the base-words are in most

11 This model is not intended to uniformly reduce such kennings to a purely mechanical process. The intention here is to draw attention certain ways that kennings appear to have functioned in the poetic tradition. The intuitive aspect of processing the poetry could also have provided a resource for poets. For example, the line ósvifr Kraka drifu (Grani Har $1^{\mathrm{II}} .2$ ) '...snowstorm of Kraki (legendary king)' would appear initially as a battle-kenning (cf. 2a-b below). This becomes the determinant for a valkyrie-name in the following line (Hlokk i harða pjokkum), leading it to be reinterpreted as a silver/gold kenning (cf. Meissner 1921: 224, 228) to form a woman-kenning (VALKYRIE OF GOLD). In this case, the semantic play with a battlekenning is likely strategic: the verse states that this woman will not stop weeping owing to the aggressive deeds of the king being praised.

12 E.g. Anon Liðs 4 $4^{\mathrm{I}} .7-8$, Svert Lv 2IV.3-4 and Edáð Banddr 5 ${ }^{\mathrm{I}} .5-6$ - N.B. that the use of adjectives may nevertheless be syntactically important, e.g. for forming a prepositional phrase in which the preposition is in a different line, as in ESk Ingdr $4^{\mathrm{II}} \cdot 3-4$ and HólmgB Lv $2^{\mathrm{V}} \cdot 3-4$. Citations of verses are by sigla and stanza numbering of the Skaldic Database. Citations are with reference to the published editions of the associated Skaldic Poetry of the Scandinavian Middle Ages edition where these were available and with reference to Finnur Jónsson's critical edition (1967) where they were not. 
cases equivalent to the determinants in terms of syllabic quantity, yet the inversion of word order to $1(\mathrm{p}) \mathrm{XxYy}$ - the word order conventional to type 12(p) $\mathrm{XYy}$ - is almost never found. ${ }^{13}$ The base-word of a 1 (p)YyXx kenning is in the position to carry rhyme in the line, and the examples foreground evidence of conventionalised rhyme-pairs in realisations of this basic type. Evidence of rhyme-pairs can then be looked at in relation to evidence of variation in determinants with special attention to uses of proper names.

Of the 80 examples, 25 or $31 \%$ employ a proper name as a determinant. This proportion is notably higher than in $12(\mathrm{p}) \mathrm{XYy}$, which exhibited approximately one in six or a bit more than $16 \%$, and this relative frequency dropped to one in eleven or about 9\% if the crystallised expression gnýr Gunnar = 'roar of Gunnr' is counted only once. As with 12(p)XYy, metrical entanglement of the lexicon is also evident in this case. For example, 12 of these 80 examples (15\%) present vápna = 'of weapons' as the determinant (9 of 12 preceded by a preposition). This frequency is more striking in light of the pilot study, where vápn appeared as a high-frequency determinant in the general statistics, yet its use appeared connected to only two metric-structural types. This makes it reasonable to consider use of vápn in 1(p)YyXx to be conventionalised. However, the present case study focuses on the possibility that whole semantic categories of heiti may become metrically entangled as preferred word-choices for co-occurrence with certain base-words. It presents evidence that, when realising basic type 1(p)YyXx battle-kennings, the selection of base-word-determinant combinations does not appear free in all cases. Certain base-words predominantly (but not necessarily exclusively) co-occur with determinants from a particular equivalence class. This is interpreted as reflecting an indexical association

13 The marked exception is uses of the base-word lexical set prima/pryma/pruma = 'thunder, noise' that in the pilot study was found exclusively in $12 \mathrm{Xx} 56$ constructions, suggesting general metrical entanglement of the lexical item(s). This base-word accounted for all but one example of generative constructions in basic types 12XxYy and YyXx56 (8 examples total), with the implication that these were related to the metrical entanglement of prima/pruma/pryma rather than being freely generative. The only other example that I have presently identified of the inverted word-order 1(p)XxYy is allprútt, éla Próttar (HSt Rst 2I .7). It is also possible to approach varat of-byrjar orva (Eskál Vell $7^{\mathrm{I}} .1$ ) and norðr - glym-hríðar borða (PjóðA Lv $3^{\mathrm{II}}$.6) as variations on a $12 \mathrm{XxYy}$ construction by regarding the element in position 2 as prefixed to the base-word for the metrical completion of the line. This element is unnecessary for the battle-kenning (of-is an intensifier whereas glymr = 'crash' can function as an independent base-word in battle-kennings - i.e. $12 \mathrm{Xx} 56 \rightarrow 1 \times \mathrm{Xx} 56$ and $1 \mathrm{X}_{2} \mathrm{X}_{1} \mathrm{x} 56$ ). However, this sort of compounding is particularly difficult to analyse on the basis of two examples when it can otherwise appear possible to view these as variations on a basic type 1XxxYy or 1X34Yy. Nevertheless, the examples appear so unusual in the dataset of the pilot-study that it is not clear that they should be regarded as reflecting a variation on a basic type as a semantic formula per se. 
or link between these base-words and a broad semantic equivalence class of heiti as determinants. This indexical linkage of categories of language in use of the register would constitute a historically structured "synchronic stylistic habit" (Foley 1993 [1990]: 192-194) that was internalised by individuals with the poetic system. ${ }^{14}$ The indexical association of a whole class of lexical items for completing a formula would be directly comparable to the conventional completion of a particular South-Slavic epic formula with 'Turkicisms', as discussed by John Miles Foley. ${ }^{15}$

The different metrical environments of odd lines and even lines condition variation in the realisations of type 1(p)YyXx battle-kennings. In odd lines, the kenning determinant always carries alliteration, which can be considered an integrated feature of the formula. There seems to be a general tendency for alliteration to be carried by the determinant and the word at the onset of the line. However, this remains a tendency and does not appear to be a prescriptive feature of formula use - in contrast to the regularity of baseword-determinant alliteration in odd-line use of 12(p)XYy battle-kennings (Frog 2014a: 126-129). Rhyme is much more regular (although not found in

14 In other words, the process of becoming competent in the poetic idiom did not simply involve internalising individual words and formulae as abstract constituents of the register. These elements were internalised in relation to situated uses, and the patterns of how and where these were used became (unconsciously) internalised with them. The limited range of uses of a word like vápn in battle-kennings is not related to metrical constraints: poets simply did not use it in other contexts, whether because they simply 'did not think of it' when forming other basic types of kennings or this heiti 'just did not sound right' in other contexts. However, when poets formed a NP 2 -GEN NP${ }_{1}$ battle-kenning of basic type 1 (p)YyXx or a $\mathrm{NP}_{2}-\mathrm{NP}_{1}$ battle-kenning of type YX3456, vápn 'came to mind'. This is an indicator that the internalisation of the formulae associated with these basic types involved the internalisation of an indexical association with vápn as a determinant - it became a 'natural' word-choice. The discussion below will focus on similar indices that develop between a base-word used in the basic type and the words with which it co-occurs.

15 Following Foley, the verb učiniti = 'to do, make' is a Turkish loan used within the formula [x] učin-ijo/-ili/-ila/-iti/etc., where the [x] is a two-syllable object of the verb and the formula forms the second colon of an epic line. Of the 164 examples of this formula surveyed by Foley, 145 were completed by Turkish loans while only 19 were completed by a vernacular term. This provides evidence that the formula was internalised with an indexical association with 'Turkicisms' as a category for completing the formulaic unit. (Foley 1993 [1990]: 192-194.) It may be pointed out that this does not mean that singers were conscious of $u$ činiti as a Turkish loan (which may be contested) or even of the elements completing the line as Turkish loans (any more than an English speaker would be conscious of a Latinate versus a Germanic etymology in the background of preferred lexical choices in certain registers). Instead - and indeed however its background might be historically reconstructed - this is an illustration of the conventionalisation of completing a formula within a broad category of lexical items. 
every line): ${ }^{16}$ rhyme is almost always carried by the base-word and a syllable in one of the first two positions in the line. Two of the exceptions may be attributed to metrical variation in which the first and third positions of the line carry rhyme and the fifth does not (4a.iv, 6.iii). The latter of these is from Snorri Sturluson's (1178-1241) illustration of what he describes as a distinct verse form called Fleins háttr = 'Fleinn's verse-form' in his ars poetica known as Edda (Háttatal 57, Faulkes 1999: 25). ${ }^{17}$ Rhyme between the base-word and determinant only occurs in four instances, in which both elements also carry alliteration: Viðris veðr = 'weather of Viðrir (Odin)' (3b.iii), Ilmar jalmr = 'yammer of Ilmr (valkyrie)' (5b.ix) and two examples of Ala él = 'squall of Áli (hero)' (8.ii-iii). It is striking that all four have proper names as determinants. It is also striking that $10(77 \%)$ of the 13 examples of this basic type in which alliteration is carried by both parts of the kenning have a proper name as a determinant (3b.3-4, 4b.ii-iii, 5b.vii, 5b.ix, 8.ii-v; cf. 1b.ii, 7.vi, 8.vi). However, the number of examples remains too limited to draw any conclusions. This observation will be therefore be left aside and returned to in the third part of this series, where attention will turn to patterns of preferred semantic categories associated generally with a metric-structural type.

In even lines, the first (stressed) syllable in the line carries alliteration with the preceding line while neither element in the kenning can alliterate with this syllable or with each other. In these lines, rhyme is invariably distributed between the base-word at the end of the line and one of the first two metrical positions (otherwise it is absent). This means that the determinant in

16 Rhyme may be imperfect in 3a.iii (-eð- rhymed with -eðr-). Some of the examples which might be described as lacking a rhyme exhibit a subtle rhyme between the onset syllable and following preposition or other light part of speech (3b.1, 3b.v, and possibly also $4 \mathrm{~b} . \mathrm{i}-\mathrm{ii}$, 8.iv). Although equivocal, this could potentially be an alternative strategy to conventional rhyme for integrating lines into the preferred acoustic texture of the poem (cf. Frog \& Stepanova 2011: 201; Frog 2014b: 19-20).

17 Snorri formally differentiates this and certain other metrical variations as verse forms distinct from the dróttkvoett metre proper. These metres are treated here as dróttkvoett because they are unambiguously variations of the basic drottkvoett metre. It should be noted that, on the one hand, Snorri's distinction of 'verse forms' was not grounded strictly in terms of metrics in the modern sense, and on the other, he was systematising and formalising skaldic poetics. His tour de force of illustrating and explicating more than 90 verse forms was in many cases built on systematising a variation for composing a couplet as a basis for a complete, eight-line stanza. In addition, Snorri's differentiation between what he views as acceptable and what 'old poets' viewed as acceptable suggests that Snorri's differentiation of certain metrical and stylistic variations as 'not dróttkveett' cannot be assumed to represent a uniformly conventional view held by all poets in all periods, or even to represent all poets in $13^{\text {th }}$ century Iceland. (See Faulkes 1999.) 
1(p)YyXx battle-kennings never carries rhyme or alliteration in even lines. Lexical choice in this position is therefore conditioned by syllabic but not by phonic constraints. This was also observed in even-line 12(p)XYy battlekennings. In that case, heiti filling the position in the middle of the line were not prompted to vary in relation to the surrounding phonic environment (except insofar as extra alliteration or rhyme in the line should be avoided). This allowed lexical items to crystallise as preferred elements for realising battle-kennings of this metric-structural type, and enabled the emergence of $d y n r=$ 'din' and gnýr = 'roar' in lexically crystallised formulae within the 12(p)XYy basic type battle-kennings (Frog 2014a: esp. 122-124). The corresponding conditions in basic type $1(\mathrm{p}) Y y X x$ make it is less surprising that vápn is found as the determinant in 9 of the 30 even-line examples, or in approximately one in every three.

\section{Inclinations to Crystallisation in 1(p)YyXx}

Example set $(1 \mathrm{a}-\mathrm{b})$ presents realisations of $1(\mathrm{p})$ YyXx with the base-word senna = 'flyting, insult exchange.' These offer a pronounced illustration of how the formula is realised in the differing metrical environments of even and odd lines. The even-line variants exhibit marked crystallisation, with 4 cases of the collocation of the base-word and the determinant ( $v a$ pn $)$, and 4 overlapping cases of the collocation of the base-word and the rhyme-word (maðr $=$ 'man') plus a preposition. Together, these realise the same full line in three of the cases. In contrast, uses of the same base-word in odd lines appear to be in free variation.

\section{(1a) 1 pYy-sennu in even lines}

\begin{tabular}{|r|l|l|l|}
\hline $\mathbf{1}(\boldsymbol{p})$ & $\boldsymbol{Y} \boldsymbol{y} \boldsymbol{X} \boldsymbol{x}$ & Translation of $(\boldsymbol{p}) \boldsymbol{Y} \boldsymbol{y} \boldsymbol{X} \boldsymbol{x}$ & Source \\
\hline menn at & vápna sennu & '...at the flyting of weapons' & Hfr ErfÓl $3^{\mathrm{I}} .2$ \\
\hline menn at & vápna sennu & '...at the flyting of weapons' & PjóðA Magnfl $9^{\mathrm{II}} .6$ \\
\hline menn at & vápna sennu & '...at the flyting of weapons' & Grett Lv $36^{\mathrm{V}} .4$ \\
\hline enn til & vápna sennu & '...to the flyting of weapons' & Skarp Lv $9^{\mathrm{V}} .2$ \\
\hline menn at $^{18}$ & odda sennu & '...at the flyting of points' & Anon Krm $17^{\mathrm{VIII}} .4$ \\
\hline
\end{tabular}

18 The manuscript variation mann $i=$ 'man in' changes the plural to a singular with skothending rhyme rather than the aðalhending rhyme. 
(1b) 1 pYy-sennu in odd lines

\begin{tabular}{|c|c|c|c|}
\hline $1(p)$ & $Y y X x$ & Translation of $(p) Y y X x$ & Source \\
\hline Gunnr um & geira sennu & '...during the flyting of spears' & Skarp Lv $11^{\mathrm{V}} .3$ \\
\hline linnr kná & sverða sennu & '...the flyting of swords' & SnSt Ht $6^{\mathrm{III}} .5$ \\
\hline enn at & eggja sennu & '... at the flyting of blades' & Tindr Lv $1^{\mathrm{V}} .5$ \\
\hline enn mun & Qrva sennu & '...the flyting of arrows' & Ptréf Lv $1^{\text {IV }} .5$ \\
\hline mins at & malma sennu & '...at the flyting of metals' & Hfr Lv $23^{\mathrm{V}} .3$ \\
\hline
\end{tabular}

A corresponding but more flexibly realised pattern can be seen in examples with the base-word drifa = 'snowstorm' (2a-b). In these, drifa rhymes with lif in 4 of 5 odd-line examples. A dash indicates a syntactic break - i.e. that different parts of the line belong to separate syntactic statements. This must be stressed because a syntactic break indicates that the collocation lif-drifa is not associated with realising a single, coherent semantic unit. It therefore does not qualify as a formula according to the approach used here.

\section{(2a) 12Yy-drifu in even lines}

\begin{tabular}{|c|c|c|c|}
\hline $1(p)$ & $Y y X x$ & Translation of $(p) Y y X x$ & Source \\
\hline gjoffrífr - & Háars drífu & '...the snowstorm of Hárr (Odin)' & Refr Frag $1^{\mathrm{III}} .2$ \\
\hline lífkǫld & Háars ${ }^{19}$ drífu & '...the snowstorm of Hárr (Odin)' & Eskál Vell $10^{\mathrm{I}} .8$ \\
\hline mitt líf - & Heðins drífu & '...the snowstorm of Heðinn (king)' & VGl Lv $11^{\mathrm{V}} .4$ \\
\hline Qrt líf & Sigars drífu & '...the snowstorm of Sigarr (king)' & GunnHám Lv $6^{\mathrm{V}} .8$ \\
\hline líf sitt - & boga drífu & '...the snowstorm of bows' & ESk Ingdr $4^{\mathrm{II}} \cdot 3-4$ \\
\hline
\end{tabular}

(2b) 12Yy-drifu in odd lines

\begin{tabular}{|r|l|l|l|}
\hline $\mathbf{1}(\boldsymbol{p})$ & $\boldsymbol{Y} \boldsymbol{y} \boldsymbol{X} \boldsymbol{x}$ & Translation of $(\boldsymbol{p}) \mathbf{Y} \boldsymbol{y} \boldsymbol{X} \boldsymbol{x}$ & Source \\
\hline hæfr at & Hlakkar drífu & '...the snowstorm of Hloqkk (valkyrie)' & HólmgB Lv 6‥3 \\
\hline áðr í & Qrva drífu & ¿...the snowstorm of arrows' & Bjbp Jóms 30 .5 \\
\hline
\end{tabular}

The lif-drifa rhyme collocation should be seen as a compositional resource that is complementary to the battle-kenning as a metrically entangled semantic formula (cf. Frog 2009: 233-239). This rhyme collocation itself appears to be metrically entangled with the 1 (p)YyXx formula, so that when the formula is realised with drifa it is already equipped with a rhyme-word for realising a metrically well-formed line (noting also that lif is not found independent of

\footnotetext{
19 Manuscripts also have Haralds in this position, which is metrically acceptable although odd as a determinant in kennings.
} 
drifa in any identified lines with 1 (p)YyXx battle-kennings). ${ }^{20}$ Uses of $d y n r$ and gnýr in basic type 12(p)XYy similarly combine with the almr-hjalmr-malmr conventional rhyme-set (cf. Frog 2014a: examples 1a.xi-xiv and 2a.x-xi) to form a verbal compositional system that I have elsewhere discussed as a 'multiform' for realising metrically well-formed lines (see Frog 2009: 239-243). ${ }^{21}$ The pilot study on the metric-structural types of battle-kennings revealed that the metrical entanglement of rhyme-pairs in this way was not exceptional, and that rhyme-pairs can exhibit collocations exclusively in relation to a metricstructural type (Frog forthcoming).

In contrast to examples with senna (1a-b), 5 of the 7 examples with drifa employ a personal name as a determinant: twice the Odin-name Hárr = 'High One', once the valkyrie-name Hlokk and the names of two mytho-heroic kings, Heðinn and Sigarr. In even lines, the pattern of distribution between the 4 examples of the rhyme collocation (lif-drifa) and the 4 uses of a personal name determinant across 5 examples parallels the distribution of recurrent lexical material in examples with senna (menn-senna and vápna-senna). The predominance of personal names here is more striking because word-choice of the determinant in even lines is not conditioned by meeting alliteration or rhyme. In other words, when these lines present the same conditions that can enable lexical stability in the role of vápn above, the predominance of $80 \%$ of determinants as personal names is a striking anomaly. In accordance with

20 Within the pilot study, the lif-drifa collocation was found in two of the three examples of drifa in this basic type and in two of the three examples of drifa's use in compounds of basic type YXx456. This collocation accounted for 4 of the 5 cases in which drifa carried rhyme in these two basic types. Within the pilot study, drifa was attested in 10 examples across 5 basic types and carried rhyme in 9 of these instances.

21 'Multiform' was coined as a formally defined technical term by Lauri and Anneli Honko (1995; 1998; see also Honko 1995; 1998: 100-116; 2003: 113-122) in order to describe systems of formulaic expressions and words that are associated in the memory of an individual singer and that provide a flexible framework for producing expression. The multiform is considered to function as a system at the level of verbalisation or texture rather than necessarily realising a specific unit of content or meaning. This initial approach to multiforms was concerned with particular questions about flexibility in epic reproduction that had not yet been sufficiently explained through Oral-Formulaic Theory. The Honkos were not concerned with the phenomenon of multiforms per se. In several articles on different oral poetries, I have significantly developed and refined the approach to multiforms, introducing the concept of equivalence classes, metrical and semantic conditioning in lexical variation, syntax and also typologies, as well as situating multiforms systematically in relation to linguistic formulae defined in terms of morpheme-equivalent units (Frog 2009; 2010; 2011; 2012; cf. also Drout 2011). The dynamics of multiforms in skaldic dróttkveett composition may be exceptional in their complexity in proportion to the size of the unit they are conditioned to realise. 
conventions of this basic type of battle-kenning, the personal name carries alliteration in the odd-line example, but the frequency of personal names still appears high. ${ }^{22}$ The lack of use of personal names as a determinant for senna may be connected to a broader pattern of use of this term as a base-word in the register: according to Rudolf Meissner's (1921: 198) fairly comprehensive survey of kennings in the skaldic corpus (including all metres), personal names are not attested as a determinant for senna-based battle-kennings. Meissner's (1921: 178) examples for drifa present a different picture: of 14 simple or basic battle kennings (i.e. with not more than two elements), 6 or just under half have a proper name as a determinant. However, half of Meissner's examples are 12 Yy-drifu battle-kennings, without which only 1 of the 7 remaining examples have a proper name as a determinant. Against the background of Meissner's survey, the use of proper names in $12 \mathrm{Yy}$-drifu battle-kennings appears quite prominent, as does the proportionate number of drifa-based battle kennings of the metric-structural type. This could be a statistical anomaly, yet a corresponding pattern emerges in uses with veðr = 'weather' as a base-word:

(3a) 1 (p)Yy-veðri in even lines

\begin{tabular}{|r|l|l|l|}
\hline $\mathbf{1}(\boldsymbol{p})$ & $\boldsymbol{Y} \boldsymbol{y} \boldsymbol{X} \boldsymbol{x}$ & Translation of $(\boldsymbol{p}) \mathbf{Y} \boldsymbol{y} \boldsymbol{X} \boldsymbol{x}$ & Source \\
\hline Jóans feðr & Hnikars veðri & '...the weather of Hnikarr (Odin)' & Svert Lv 2 IV $^{2}-4$ \\
\hline hleðr í & Gunnar veðri & $\begin{array}{l}\text { '...in the weather of Gunnr } \\
\text { (valkyrie)' }\end{array}$ & Pfagr Sveinn $5^{\mathrm{II}} .4$ \\
\hline heðan í & róstu veðri & '...in the weather of a riot' & SvB Lv $3^{\mathrm{V} .2}$ \\
\hline
\end{tabular}

(3b) 1 (p)Yy-veðr-INFL in odd lines

\begin{tabular}{|c|c|c|c|}
\hline $1(p)$ & $Y y X x$ & Translation of $(p) Y y X x$ & Source \\
\hline hvar er í & Hildar veðri & '...in the weather of Hildr (valkyrie)' & Grett Lv $14^{\mathrm{V}} .3$ \\
\hline heiðr at & Hildar veðri & '...at the weather of Hildr (valkyrie)' & GDrop Lv $4^{\mathrm{V}} .7$ \\
\hline
\end{tabular}

22 It may also be worth observing the line vifs gørninga drifu (Bbreiðv Lv $6^{\mathrm{v}} .8$ ) = 'sleet of the wife of sorcery', where the rhyme with drifa in the line is accomplished with the base-word of a valkyrie-kenning (i.e. equivalent to Hlokk), which is itself the determinant for line-final drifa in the formation of the battle-kenning. This is a complex kenning that is not a variation on basic type 1(p)YyXx. Although analysable as basic type Y234Xx + XYyy56 = YZzzXx, neither basic type would be a conventional basic type for battle-kennings, and the occurrence of the baseword in positions 5-6 appears generally exceptional for battle-kennings. Future studies of the different basic types of a semantic formula will make it possible to assess the degree to which the sort of indexical associations addressed here are specific to a metric-structural type or may be shared across types in which e.g. the base-word occurs in particular metrical positions (e.g. when $\mathrm{Xx}=$ positions $5-6$ ). 


\begin{tabular}{|c|c|c|c|}
\hline Dreif at & Viðris veðri & '...at the weather of Viðrir (Odin)' & Tindr Hákdr $3^{\mathrm{I}} .1$ \\
\hline naðrí & Virfils veðri & $\begin{array}{l}\text { '...in the weather of Virfill } \\
\text { (mythic king)' }\end{array}$ & Grett Hallfl $2^{\mathrm{V}} .3$ \\
\hline Skýtr at & Skoggla & $\begin{array}{l}\text { '...at the weather of Skogul } \\
\text { (valkyrie)' }\end{array}$ & SnSt Ht $54^{\mathrm{III}} .1$ \\
\hline glaðr - í & $\begin{array}{l}\text { Gǫndlar } \\
\text { veðrum }\end{array}$ & $\begin{array}{l}\text { '...in the weather of Gondul } \\
\text { (valkyrie)' }\end{array}$ & Eskál Vell 6. 3 \\
\hline teðr - í & tognings veðri & '...in the weather of the sword 3 & Balti Sigdr $3^{\text {II }} .3$ \\
\hline
\end{tabular}

Here, 8 of 10 examples employ proper names: five with valkyrie-names (Hildr twice, Gunnr, Gondul, Skogul), two with Odin-heiti (Hnikarr, Viðrir), and one with the name of a mytho-heroic king (Virfill). The Odin-heiti also appears in a variation in the couplet pryngr at Viðris veðri / vandar, góðr fyr hondum (Vígf Lv $\left.1^{\mathrm{I}} .3-4\right)$, where the complex kenning Viðris vandar veðr = 'the storm of the rod of Viðrir' = 'storm of the SWORD/SPEAR' = BATTLE] can be seen as an extension of Viðris veðr (3b.iii) without compromising the form or semantics of the basic type. This type of variation was also observed in basic type 12(p)XYy where the verbally crystallised formula Gunnar gnýr = 'roar of Gunnr (valkyrie)' was extended to Gunnar gagls gnýr = 'roar of the bird of Gunnr' = 'roar of the raven' = BATTLE] (123-gný-Gunnar/gagls-23456) (Frog 2014a: 124-125). According to Meissner's survey, the use of proper names with veðr is much more common: 19 of the 38 basic kennings, or 50\%. This drops to 11 of 28 without examples of 1 (p)YyXx battle-kennings, and thus the $80 \%$ of proper name determinants in the type can be contrasted with 39\% in all other types and metres. The use of proper names with $v e ð r$ can therefore be considered exceptionally pronounced in basic type 1 (p)YyXx. Nevertheless, the proper names extend across semantic categories of heiti - they are not exclusively valkyrie-names or Odin-heiti.

\section{Infrequent Base-Words in 1(p)YyXx}

This prominence in the use of proper names with drifa and veðr not only contrasts with their absence in use with senna $(1 \mathrm{a}-\mathrm{b})$, but also with the use of proper names accompanying low-frequency base-words in identified $1(\mathrm{p}) \mathrm{YyXx}$ battle-kennings. For the present discussion, base-words will be considered lowfrequency in a type if they are found only in five examples or less. Although 7 examples of $1(\mathrm{p}) Y y X x$ are found with the base-word leikr = 'play, sport, game', 4 of these are found in a single poem, which may skew the image of 
its frequency. Examples with leikr are therefore listed here as potentially lowfrequency $(4 a-b)$ :

(4a) 1 pYy-leiki in even lines ${ }^{23}$

\begin{tabular}{|c|c|c|c|}
\hline $1(p)$ & $Y y X x$ & Translation of $(p) Y y X x$ & Source \\
\hline Qrn at & sverða leiki & '...at the play of swords' & Anon Krm $22 V^{\mathrm{III}} .8$ \\
\hline gaukr at & sverða leiki ${ }^{23}$ & '...at the play of swords' & Anon $\mathrm{Krm} 16 \mathrm{~V}^{\mathrm{III}} .4$ \\
\hline bleikr frá & sverða leiki & '...from the play of swords' & Anon (TGT) $30^{\mathrm{III}} .2$ \\
\hline hogg at & eggja leiki & '...at the play of blades' & Рjóð Lv 1 ${ }^{\mathrm{I}} .2$ \\
\hline
\end{tabular}

(4b) 1 pYy-leiki in odd lines

\begin{tabular}{|r|l|l|l|}
\hline $\mathbf{1}(\boldsymbol{p})$ & $\boldsymbol{Y} \boldsymbol{y} \boldsymbol{X} \boldsymbol{x}$ & Translation of $(\boldsymbol{p}) \mathbf{Y} \boldsymbol{y} \boldsymbol{X} \boldsymbol{x}$ & Source \\
\hline hversu at & logðis leiki & '...at the play of the stabber (sword)' & Anon Krm $21^{\mathrm{VIII}} .7$ \\
\hline hǫtt at & Hildar leiki & '...at the play of Hildr (valkyrie)' & Anon Krm 13 ${ }^{\mathrm{VIII}} .3$ \\
\hline margr var at & Laufa leiki & '...at the play of Laufi (sword)' & Bjbp Jóms $18^{\mathrm{I}} .7$ \\
\hline
\end{tabular}

Proper names are found in 2 of the 7 examples with the base-word leikr = 'play, sport, game' (4b.ii-iii) (cf. also Meissner 1921: 199). One is the valkyrie-name Hildr (4b.ii) and the other is the name of a mytho-heroic sword Laufi (4b.iii). $L$-alliteration is not frequent (cf. Hollmérus 1936). Word choice in the combination of Laufi and leiki has undoubtedly been conditioned to some degree by phonic demands of alliteration. Although alliteration could be considered a determinant in word-choice, Laufi seems always to alliterate when used as a heiti in dróttkveett poetry more generally while the sword-heiti logðir = 'stabber' (4b.i) shows that equivalent terms capable of $l$-alliteration were also available. It seems worth observing that 5 of the 7 examples of this basic type are quite specifically sword-heiti while a sixth can be interpreted that way as well (cf. English blade as a synonym for 'sword'). It is at least possible that semantics of an entangled equivalence class could have been involved here.

Additional examples of low-frequency base-words that are found three times or less in this data present 25 examples (5a-b) ${ }^{24}$ This presents one case of full-line correspondence between two poems (5a.iii-iv; N.B. the syntactic break in the line of one but not the other), a second case of variation only in the preposition (5a.i-ii), and a total of 7 examples employing the determinant vápn (5a.iii-vii, 5b.ii, 5b.xiv), discussed above.

\footnotetext{
23 A variant of this line reads: "geto vid soknar lęte" (getu við sóknar loeti).

243 x ping, snerra; 2 x galdr, glygg, gnaustan, hagl, mót, jalmr; 1 x brestr, byrr, flaumr, glamm, kveðja, rodd, teiti.
} 
(5a) 1 (p)YyXx in with low-frequency base-words in even lines

\begin{tabular}{|c|c|c|c|}
\hline $1(p)$ & $Y y X x$ & Translation of $(p) Y y X x$ & Source \\
\hline gagls fyr & strengjar hagli & '...before the hail of the string' & ESk Ingdr $3^{\mathrm{II}} .6$ \\
\hline gagls við & strengjar hagli & '...at the hail of the string' & Hfr Hákdr $3^{\mathrm{III}} .2$ \\
\hline hjaldrs at & vápna galdri & '...at the chant of weapons' & ESk Geisl $43^{\mathrm{VII}} .2$ \\
\hline hjaldrs - at & vápna galdri & '...at the chant of weapons' & Pmáhl Máv 10.6 \\
\hline framm í & vápna $\mathrm{g}$ & '...at $\mathrm{t}$ & $\operatorname{lgn} 7^{\mathrm{II}} .8$ \\
\hline geystir - & vápna $b$ & '...the & Bjbp \\
\hline Hringr á & vápna pingi & ceombly of wo & \\
\hline yrpjóð - & Heðins b & & $21^{\mathrm{I}} .8$ \\
\hline draum í & sverða fl & '...in $t$ & $3^{\mathrm{III}} \cdot 4$ \\
\hline austr ór & malma g & $\therefore$ out of the gnash o & Hfr ErfÓl $22^{\mathrm{I}} .2$ \\
\hline hjalm at & geira & ‘...at & Arn Porfdr $10^{\mathrm{II}} .2$ \\
\hline veitk sonn - & Hugins teiti & '...the joy of Huginn (raven)' & ESk Geisl $41^{\mathrm{VII}} \cdot 6$ \\
\hline ritr - at & hjalma móti & '....at the meeting of helmets,' & Anon Krm $7^{\mathrm{VIII}} .8$ \\
\hline
\end{tabular}

(5b) 1 (p)YyXx in low-frequency base-words in odd lines

\begin{tabular}{|c|c|c|c|}
\hline $1(p)$ & $Y y X x$ & Translation of $(p) Y y X x$ & Source \\
\hline Mér lízt & malma snerru & '...the onslaught of metals' & HǫrðG Lv 10‥1 \\
\hline verr hafa & vápna snerru & ight of weapons' & \\
\hline Qrrí & odda s & '...in the onslaught of points' & Sveinn $2^{\text {II }} .3$ \\
\hline sǫng at & sverða pingi & mbly of swords, & r Hákdr $2^{\mathrm{I}} .7$ \\
\hline geng ek & geira pingi & mbly of spears, & HólmgB Lv $2^{\mathrm{V}} .3$ \\
\hline sleit at & sverð & $\therefore$...at tl & $\operatorname{ddr} 5^{\mathrm{I}} .5$ \\
\hline $\mathrm{r}$ at & Gǫn & '...at t & $\mathrm{Sn}$ \\
\hline viggs, í & vápna glyggvi & & $2^{\mathrm{II}} .7$ \\
\hline búumk við & Ilmar $^{26}$ jalmi & & \\
\hline Hræddr fór & hjorva ${ }^{27}$ raddar & & $r 8^{\mathrm{I}} .1$ \\
\hline mest, í & malma gnaustan & ‘..in & \\
\hline mjǫð, fyr & malma kveðju & '...before the greeting of metals' & Sigv Nesv $7^{\mathrm{I}} .7$ \\
\hline
\end{tabular}

25 Manuscript variants also present $g r t$ and snertu in this line, forming a different but correct rhyme.

26 The manuscript variant almir = 'elms' is metrically viable but dissolves the kenning and changes the sense.

27 Manuscript variants with hjarta = 'of hearts' are metrically acceptable but semantically peculiar. 
Proper names are found in only 4 of 25 examples that have base-words occurring three times or less (5a-b): the valkyrie-names Gondul (5b.iv) and Ilmr (5b.ii), the name of a mytho-heroic king Heðinn (5a.vi), and the name of Odin's raven Huginn (5a.xi), which is otherwise exceptional for battle-kennings (cf. Meissner 1921: 201). The valkyrie-name or goddess-name (?) Ilmr is both infrequent and obscure (Hopkins 2014). Although vocalic alliteration is the most frequent type of alliteration in Germanic verse, mythic female names capable of functioning as a valkyrie-heiti with this alliteration seem to have been limited to only two (Price 2002: 338-340). The use of these particular names in battle-kennings seems to have been exceptional (cf. Egilsson \& Jónsson 1931: 104 s.v. '1. eir', 319 s.v. '2. Ilmr', and cf. 661 s.v. 'Qlrún'). The appearance of Ilmr in this case rather than the Odin-heiti Yggr (13.iv-v) or the hero-heiti Áli (13.ii-iii) may be directly related to its function of carrying both alliteration and rhyme, in which case the lexical choice would be determined by phonic requirements. Among examples with infrequent referents, the variation Gríms í gondlar flaumi / Gefnar mák of hefna (VGl Lv $\left.11^{\mathrm{V}} .7-8\right)$ can also be mentioned. This has been interpreted not as a variation of Gondlar flaumr = 'rush/eddy of Gondul', which would be semantically sufficient: as an extended kenning, gondul shifts to function as a common noun in a complex kenning with the Freyja-heiti Gefn in the kenning gondlar Gefnar flaumr = 'rush/eddy of the Gefn of (battle?) ${ }^{28}$ ' = 'rush/eddy of the valkyrie'. In this case, complementing the kenning with Gefn simultaneously accomplished alliteration with the preceding line and accomplished the rhyme in the line in which it appeared. This is directly comparable to the cases of Viðris (vandar)

28 The valkyrie-name Gqndul has the appearance of a feminine form of the obscure term gondull (listed with two attestations in The Dictionary of Old Norse Prose). Gondull is thought to be a term for a staff used in controlling gandr-spirits in magical practices. The valkyrie-name, however, has been thought to derive independently from gandr; to stem from a poetic meaning 'wolf' and thus refer to beasts of battle (Tolley 1995: 69-71; Price 2002: 341). Gondull = 'staff, wand' would be appropriate as a sword-heiti and could provide a base of interpretation here (cf. Price 2002: 338). However, according to the database of Eysteinn Björnsson (-2001), this would be exceptional for a valkyrie-kenning because GODDESS OF IMPLEMENT(S) OF BATTLE appears almost exclusively in the form of complex kennings. Moreover, the form of the word here is the feminine gondul. One of the anonymous reviewers of this article made the insightful suggestion that gondul functions here as a battle-heiti. This would conform to the most common pattern of using a goddess-heiti as a base-word in a valkyrie-kenning (Björnsson -2001). This interpretation is viable irrespective of the etymology of Gondul: almost all valkyrie-names can be interpreted as battle-heiti or battle-kennings (cf. Price 2002: 338-340), and therefore the potentially opaque gondul could be inferred by poets to function in the same way. On the other hand, a variation of this type may have been formulaic (and equally so with Viðrir and Gunnr) without requiring consideration of possible shifts in semantics of these names (cf. Frog 2014a: 125n.44). 
veðr and Gunnar (gagls) gnýr mentioned above. Thus, the doubling of viable terms for mythological beings appears directly associated with meeting metrical demands and potentially for aesthetic effect. Such examples are illustrative of poets playing with conventionalised resources of tradition in composition.

The frequency of personal names with the low-frequency base-words is slightly more than $16 \%$ - directly comparable to basic type $12(\mathrm{p}) \mathrm{XYy}$ battlekennings when the 5 examples of the conventionalised expression gnýr Gunnar are included in the tally. This does not reveal a concentration that is strikingly anomalous. The personal names are also not bound up with a specific category of being, which contrasts with examples of 12(p)XYy battle-kennings. However, the diversity of proper names here might be compared with the semantic fluidity between different heiti for weapons and armour as 'implements of battle' - i.e. 'Odin', 'valkyrie' and 'mythic hero/king' may all be seen as mythic 'agents of battle. The use of proper names in the examples with drifa $(2 \mathrm{a}-\mathrm{b})$ and $\nu e ð r(3 \mathrm{a}-\mathrm{b})$ remains striking. These are both weather-heiti, as are glygg = 'wind, gale' (5b.viii-ix) and more loosely byrr = 'fair wind, good wind for sailing' (5a.viii) ${ }^{29}$ If weather-heiti are separated from the lowest-frequency terms above (5a-b), 2 of 4 of these are collocated with personal names while only 2 in 20 are found with other semantic categories of base-words. Of the latter two, the kenning Hugins teiti is generally exceptional: the base-word teiti= 'joy' in 'joy of the raven' would normally refer to corpses on which they feed (cf. Meissner 1921: 203). ${ }^{30}$ Although half of the personal-name determinants appear in two of the five examples of weather-heiti, there are so few examples of the individual base-words that this could simply be accidental.

\section{Base-Words Entangled with Odd-Line 1(p)YyXx}

This brings us to the final three groups of examples of metric-structural type 1(p)YyXx: those with the base-words skúr = 'shower', hrí = 'storm' and él = 'squall', all of which are weather-heiti. With a total of 21 examples, these three groups together comprise more than one quarter of the examples of this type. Whereas examples with drifa (2a-b) and veðr (3a-b) as well as

\footnotetext{
29 Meissner (1921: 181-182) made more sensitive distinctions of semantic categories of base-
} words than is done here and addresses byrr more specifically as a wind-heiti.

30 Use of teiti can be considered to function here as a metonym for battle (i.e. as the supplier of the corpses which bring the raven joy). The use of the proper name of Odin's raven does not meet demands of either alliteration or rhyme and may therefore remain striking in this construction. 
other terms exhibit use across odd and even lines, these last three examples appear particular to odd lines. This suggests that these base-words are metrically entangled with this metric-structural type of battle-kenning in a way that conditions their use to certain types of lines (or rhythms). They may potentially reflect lexically conventionalised formulae. However, the patterns of use could perhaps also reflect a type of preferred lexical choice within a concentrated lexical equivalence set (cf. also the predominance of $v e \partial r$ in odd lines). Use in odd lines presents the metrical requirement that two stressed syllables in the line should carry alliteration. In identified examples, skúr never participates in alliteration, which might be expected as this was perceived in Old Norse poetry as requiring an $s k$-alliteration (distinguished from $s$-alliteration). More surprising is that $h r i \partial$ only carries alliteration in 1 of 6 examples when $h$-alliteration (undistinguished from $h r$-alliteration) was the most common alliteration pattern after vocalic alliteration in Old Norse poetry (cf. Hollmérus 1936: 64, Table 3). Together, the 15 examples of these two terms present only one proper name as a determinant. Use of proper names with skúr in the survey of Meissner (1921: 181) show only 1 among 19 examples of basic kennings (not the same as the one below), and 6 of 67 for $h r i d$ (Meissner 1921: 180), so low frequency here is not surprising in that respect. In contrast, the final term él carries alliteration in 5 of 6 examples and also appears with a proper name as the determinant in 5 of 6 examples, which is markedly higher than the 28 of 57 or ca. $50 \%$ of examples of basic battle-kennings listed by Meissner (1921: 178-179).

(6) 1(p)Yy-skúr-INFL (odd lines only)

\begin{tabular}{|c|c|c|c|}
\hline $1(p)$ & $Y y X x$ & Translation of $(p) Y y X x$ & Source \\
\hline Hárs við & Hǫgna skúrir & '...at the showers of Hogni (hero)' & Eskál Vell 34. 3 \\
\hline hverr gerir & hjalma skúrar & '...the shower of helmets, & RvHbreiðm Hl $46^{\text {II }} .3$ \\
\hline hilmir & hjalma skúrir & '...the showers of helmets, & SnSt Ht $57^{\text {III }} .1$ \\
\hline Mér stóð & málma skúrar & '...the shower of metals' & Grett Lv $22^{\mathrm{V}} .1$ \\
\hline stendr af & stála skúrar & '...from the shower of steels' & SnSt Ht $55^{\text {III }} .5$ \\
\hline ár til & eggja skúrar & '...to the shower of edges' & Sjórs Lv $3^{\mathrm{II}} .3$ \\
\hline Jarl lætr & odda skúrar & '...the shower of points' & pjóðA Frag $2^{\mathrm{II}} .1$ \\
\hline vér hlutum & vápna skúrir & '...the showers of weapons' & Anon Liðs $4^{\mathrm{I}} .7$ \\
\hline fár má & fleina skúrar & '...the shower of shafts' & Ingj Brandfl $4^{\mathrm{IV}} .5$ \\
\hline
\end{tabular}


(7) 12Yy-hríð-INFL (odd lines only)

\begin{tabular}{|c|c|c|c|}
\hline $1(p)$ & $Y y X x$ & Translation of $(p) Y y X x$ & Source \\
\hline glaðr varð & geira hríðar 31 & '...the storm of spears, & Anon Krm $16^{\mathrm{VIII}} .3$ \\
\hline groððr pvarr & geira hríðar & '...the storm of spears' & Hfr Óldr $5^{\mathrm{I}} .7$ \\
\hline Boðit hafa & $\begin{array}{l}\text { brodda }^{32} \\
\text { hríđar }\end{array}$ & '...the storm of spikes' & HólmgB Lv $4^{\mathrm{V}} .1$ \\
\hline bíoum & brodda hríðar & '...the storm of spikes' & GSúrs Lv $32^{\mathrm{V}} .7$ \\
\hline áðr réð ek & odda hríðar ${ }^{33}$ & '...the storm of points' & Porm Lv $13^{\text {IV }} .3$ \\
\hline Njorðr nam & hjálma hríðar & '...the storm of helmets' & PormÓl Lv $1^{\mathrm{V}} .5$ \\
\hline
\end{tabular}

(8) 1 (p)Yy-él-INFL (odd lines only)

\begin{tabular}{|c|c|c|c|}
\hline $1(p)$ & $Y y X x$ & Translation of $(p) Y y X x$ & Source \\
\hline sól rauð & Svǫlnis éla & '...in the squall of Svolnir (Odin)' & HSt Rst $16^{\mathrm{I}} .3$ \\
\hline verum í & Ála éli & '...in the squall of Áli (hero)' & Gizsv Lv $1^{\mathrm{I}} .7$ \\
\hline varat í & Ála éli & $\therefore$...in the squall of Áli (hero)' & Epver Lv $2^{\mathrm{V}} .3$ \\
\hline par erí & Yggjar éli & '...in the squall of Yggr (Odin)' & Bjbp Jóms $29^{\mathrm{I}} .5$ \\
\hline bál rauðk & Yggjar éla & '...the squall of Yggr (Odin)' & Hfr Lv $14^{\mathrm{V}} .7$ \\
\hline at hann í & odda éli & '...in the squall of points' & Anon Krm $22^{\mathrm{VII}}$ \\
\hline
\end{tabular}

The name of the mythic hero Hogni appears in one example with skúr (6.i), which is interesting for not being used in alliteration with hrí $\partial$. At the same time, use of $h r i ð$ in the place of skúr in examples (6.i-iii) or (6.viii) would produce over-alliteration in the line - a factor that might be related to the fact that examples with skúr are more strongly represented in the data-set than examples with hrí or él. In contrast, él is found with the alliterating mytho-heroic name Áli (with near-full-line correspondence) (8.ii-iii) and the Odin-heiti Yggr $(8 . i v-v){ }^{34}$ It is also found with the Odin-heiti Svolnir (8.i) in the one example where él does not carry alliteration. There is a pronounced difference found across these three terms both in the participation in alliteration and in the use of proper names as a determinant. This suggests conventional differences in how these three base-words were deployed in this battle-kenning construction.

31 The manuscript variant reading "gera broder" (probably gera bró $\mathrm{xir}=$ 'make the brother') appears to lack the kenning entirely.

32 The manuscript variant brynju = 'of the armour' has no metrical or semantic consequences for the line.

33 The manuscript variant skúrar results in an absence of rhyme in the line.

34 Both of these can be considered relatively common combinations according to Meissner's survey (1921: 183). 
The limitation of evidence to odd lines should not be over-interpreted as meaning these base-words could never appear in even-line variations of this metric-structural type. A variation of this formula with skúr fills an even line with a complex battle-kenning in one case. This is in the line fúrs $i$ Próttar skúrum (Eskál Vell 11I.6) = 'the showers of the fire of Próttr' where the determinant is also an Odin-heiti Próttr. ${ }^{35}$ In this case, the additional element produces the kenning Próttar fúrr = 'flame of Odin' = swORD' without impacting the form or semantics of the 1 (p)YyXx basic type. This example should be considered in relation to those examples above in which an added element to the kenning accomplishes metrical requirements without semantic impact. The difference here is that the additional element occurs at the onset of the same line rather than at the onset of the following line. Here, as in cases already addressed, the mediating element carries both alliteration and aðalhending rhyme - a rhyme also dependent here on the choice of the base-word skúr. Although this example remains outside of the data-set as a complex kenning, it nevertheless shows that these base-words could appear in even lines, at least in variations on the basic type. The complete lack of even-line examples outside of this variation could then simply be a natural statistical outcome of their patterns of use, much as $d y n r$ is observed in only one odd-line example of battle-kenning type 12(p)XYy (Frog 2014a: examples 1a-b). It is equally possible that the base-word veðr also functioned similarly: the appearance of 3 even-line examples out of the 10 examples ( $3 a-b)$ may be an outcome of the larger number of examples (almost twice those of hríð or él) combined with a few statistically infrequent cases showing up in the data.

\section{Overview of Proper Names in 1(p)YyXx}

The number of examples for each base-word of battle-kenning type 1(p)YyXx is relatively few. If the kennings realised with a certain base-word are addressed independently, then the concentration of personal names in a particular case might seem a bit peculiar but could be dismissed as probably little more than a statistical anomaly. When co-occurrence is surveyed across all base-words and these are considered together, the use of personal names as a determinant is unambiguously concentrated around certain base-words in battle-kennings of this metric-structural type. Overall, 25 - more than 30\% - of the identified examples of type 1(p)YyXx battle-kennings have a proper name as a determinant.

35 The variation Pundr, also an Odin-heiti, is found in some manuscripts. 
However, 18 of these 25 appear in conjunction with only 3 base-words: drifa (2a-b), veðr (3a-b) and él (8). Co-occurrence with these three terms accounts for $75 \%$ of the uses of proper names in battle-kennings of this basic type. The remaining 7 proper name determinants are distributed across 18 other basewords, accounting for slightly more than $12 \%$ of the 57 examples using these base-words. This is between the ca. $16 \%$ found with basic type 12(p)XYy, and that type's adjusted calculation of $9 \%$ when the 5 uses of the conventionalised Gunnar gnýr kenning are counted only once. Although drifa, veðr and él all belong to a common equivalence class of weather-heiti, corresponding use of proper names is not associated with the base-words skúr and hrí, which belong to the same equivalence class. The pattern of metrical entanglement associated with base-words must therefore be considered to be at the level of lexical items on an individual basis rather than at the abstract level of semantic equivalence class.

Personal names used as determinants in realising type $1(\mathrm{p}) \mathrm{YyXx}$ battlekennings do not appear to be bound to a particular category of heiti such as 'Odin' or 'valkyrie', as was the case in type 12(p)XYy battle-kennings. Instead, personal names seem to function as a more fluid but distinct category which includes both terms from the heroic sphere and terms for beings associated with mythology - i.e. all proper names that can be used as simple determinants in battle-kennings with these base-words. Identifying that category as 'grammatical' (proper nouns) as opposed to 'semantic' (nameable identities) may underestimate the degree to which heiti of this broad group was most probably an intuitively internalised category within the register that might not necessarily fully correspond to ontologies or grammatical categories current outside of the register. ${ }^{36}$ The distribution of proper names as determinants in examples of type 1(p)YyXx battle-kennings nevertheless appears to reflect the metrical entanglement of a category of preferred determinants for a particular set of lexical items as base-words.

The metrical entanglement of a particular category of determinants with three base-words can be further contextualised among other patterns in the data. The general prominence of the determinant vápn = 'weapons' suggests that this determinant was metrically entangled with this battle-kenning basic

\footnotetext{
36 This observation carries the implication that additional lexical items may have been functionally identified with this group within the register but presently remain unrecognised by scholarship owing to modern presumptions about categories to which terms in the register should be assigned. It may be possible to confirm or refute this possibility through future studies of patterns in language use, which will, however, most likely require the gradual development of infrastructures in the form of research on different aspects of metrically contextualised language use in dróttkvoett as a necessary foundation and context for discussion.
} 
type. The use of vápn seems simultaneously to be a metrically entangled lexical preference at the general level (5b.ii, 5b.ix, 6.viii) of a potentially distinct socially circulating formula (1a.i-iv, 5a.ii-vii) similar to dynr (Frog 2014a: example set 1a-b) and gnýr (ibid.: example set 2a-b) - i.e. 1(p)-vápna-Xx. The potential conventionalised formula vápna senna (1a.i-iv) may be a still more crystallised realisation of this formula, a variation of it paralleling the expression gnýr Gunnar, discussed in the first part of this study (Frog 2014a: 124-125). The apparently conventionalised use with senna in even lines highlights the metrical entanglement of the lexicon with the battle-kenning basic type. The near-exclusive use of the base-words skúr (6), hrið (7) and él (8) in odd lines (cf. also veðr) indicates that the use of these words is not freely generative in the realisation of type 1(p)YyXx battle-kennings. This implies that these lexical items should be considered metrically entangled and potentially formulaic in their use - odd-line formulae of the broader semantic battlekenning formula of type $1(\mathrm{p}) \mathrm{YyXx}$. Such a possibility is highlighted by the use of proper names as determinants used with él and also by the role of él in alliteration as contrasted with uses of skúr and hrið in the same basic type. In addition, conventionalised rhyme-collocations were clearly evident in evenline uses with senna (1a) and drifa (2a) as base-words. As with the indexical association between a South-Slavic epic formula and "Turkicisms" discussed by Foley (1993 [1990]: 192-194), these sorts of indices are indications that metrical entanglement of the lexicon within the basic type has developed a further degree of formulaicity. Thus even the small sets of examples for each base-word offer indications of conventionalised patterns of language use.

This, however, returns us to Fox's (1977: 72) concern over viewing language through the lens of typology. On the basis of the preceding discussion, it is possible to extrapolate each distinctive case of patterned use as a conventional formula with variations that might be described as, for example:

(9) Examples of hypothetical abstract formulae from example sets of 1 (p)YyXx above

\begin{tabular}{|ll|l|l|l|}
\hline \multicolumn{1}{|c|}{$\boldsymbol{1}(\boldsymbol{p})$} & $\boldsymbol{Y} \boldsymbol{X}$ & $\boldsymbol{X} \boldsymbol{x}$ & \\
\hline$(1 \mathrm{a}-\mathrm{b}) \rightarrow 1(\mathrm{p})$ & ('weapons')-GEN & sennu & \\
\hline$(2 \mathrm{a}-\mathrm{b}) \rightarrow($ lif-2/1-líf) & ('agent of battle') & drífu & \\
\hline$(3 \mathrm{a}-\mathrm{b}) \rightarrow 1(\mathrm{p})$ & ('agent of battle')-GEN & veðr-INFL & \\
\hline$(6) \rightarrow 12$ & ('implements of battle') & skúr-INFL & (odd lines only) \\
\hline$(7) \rightarrow 12$ & ('implements of battle') & hríð-INFL & (odd lines only) \\
\hline$(8)$ & $\rightarrow 1(\mathrm{p})$ & ('agent of battle') & él-INFL & (odd lines only) \\
\hline
\end{tabular}


The image that this produces may present a more or less accurate descriptive abstraction of examples from the data. At the same time, this sort of description separates these 'formulae' from one another leading to an inclination to isolate them - i.e. as Formula 1, Formula 2, Formula 3, etc. This may be misleading with regard to generative use of the oral-poetic register in the production of metrically well-formed verses. This is highlighted by the potential for 1 (p)-vápna-Xx to also be regarded as a distinct formula that intersects with the models of formulae described in (9) according to grouping items by base-words.

The crystallisation of verbal elements into distinct formulae in basic type 1(p)YyXx battle-kennings is quite possible and even probable, but this would be only one quite narrow phenomenon in language practice. If the examples of verbally identical and near-identical lines above are not considered accidental (1a.i-5, 5a.i-ii, 5a.iii-iv, 8.ii-iii), then it appears that lines of socially circulating poetry could be adapted directly as a verbal template in composition. If this is the case, then more of these examples may reflect this same strategy although verbal variation in the adaptation - e.g. between equivalent heiti - is less directly observable (cf. especially 3b.i-ii, 7.i-ii). 'Paradigmatic substitution' in such an adaptation would break down the formal criteria according to which comparisons have been made above, potentially leaving the adaptation more or less undetectable according to these methods (cf. Frog 2009: 240-243). However, fluency in a register is characterised by an ability to move beyond exemplar models (of whatever sort) toward internalised patterns of language use abstracted from the patterned conventions of social practice (cf. Harvilahti 2000; Bybee 2006; Goldberg 2006). Rather than basic type 1(p)YyXx battlekennings being divided into a skúr-formula, a drífa-formula, a vápn-formula and so forth, the relationships between these could potentially be extremely fluid, metrically entangled verbal systems. In other words, by engaging the metrically entangled basic type 1 (p)YyXx as a semantic formula, a competent user of the register would also be engaging a metrically entangled verbal system conventional for appropriately realising that formula. Realising that formula through language would involve lexical choices. At that point, lexical choices such as whether to use drifa, senna or hríð as a base-word, or to use vápn, Hildr or Yggr as a determinant would index co-occurring lexical material and patterns of use (e.g. alliteration) with which these are associated in realising the particular formula. Those same patterns may equally involve closer and more distant relations between alternative lexical choices among which variation may be more natural (i.e. more likely to be intuitive and automatic). On the one hand, this would explain variation within a semantic equivalence class of determinant linked to certain base-words. On the other hand, it can also be looked at with regard to personal name determinants in terms of closeness of patterns 
of use of skúr (6) and hríð (7) as opposed to él (8), as well as él and veðr (3) as similar to drifa (2), and drifa and veðr in contrast to senna (1). At the same time, senna and drifa can be looked at in relation to veðr, él, skúr and hríð with regard to use in even and odd lines. To put it succinctly: internalised patterns of language use lead to associated patterns in generative language production within the register. The potential complexity of these processes should not be underestimated. It should also not be underestimated that, in practice, multiple strategies and resources related to the single basic type could all function in tandem. In other words, the sort of bottom-up generation of verses from an abstract 1(p)YyXx semantic formula can be seen as one potential resource. The top-down generation of verses from lexically crystallised formulae (e.g. 12 Yy-hrí-INFL) could provide a distinct resource. Socially circulating lines of poetry in which a kenning of this type was used could provide a third resource. Rather than being independent of one another, exclusive and used in isolation from one another, all of these could be complementary and in interaction.

Type 1(p)YyXx battle-kennings seem in general to exhibit patterns of the metrical entanglement of the lexicon. The concentrated use of proper names as determinants - even as a broad category - with certain base-words as opposed to others appears to be only one aspect of that phenomenon in the production of battle-kennings of this metric-structural basic type. This pattern suggests that personal names had a functional role as integrated resources in composition rather than being primarily or exclusively referential when appearing in conventional metric-structural kenning types. This supports the hypothesis that proper names associated with mythology would be a fully integrated part of the lexicon of the dróttkvoett register, although this does not exclude the possibility that these names could be used strategically for producing meanings and associations in particular cases. ${ }^{37}$

\section{References}

Abrahams, Roger D. 1969 [1976]. The Complex Relations of Simple Forms. In: BenAmos, Dan (ed.), Folklore Genres. Austin: University of Texas Press, 193-214.

Agha, Asif 2007. Language and Social Relations. Cambridge: Cambridge University Press.

\footnotetext{
37 Research presented here has been accomplished within the framework of the Academy of Finland Project "Oral Poetry, Mythic Knowledge and Vernacular Imagination" of Folklore Studies, University of Helsinki.
} 
Árnason, Kristján 1991. The Rhythms of dróttkvætt and Other Old Icelandic Metres. Reykjavík: University of Iceland, Institute of Linguistics.

Bybee, Joan 2006. From Usage to Grammar: The Mind's Response to Repetition. In: Language 82(4), 711-733.

Björnsson, Eysteinn -2001. Lexicon of Kennings and Similar Poetic Circumlocutions: The Domain of Battle. URL: https://notendur.hi.is// eybjorn/ugm/kennings/ kennings.html

Clunies Ross, Margaret (ed.) 2007. Poetry on Christian Subjects (2 vols.). Skaldic Poetry of the Scandinavian Middle Ages 7. Turnhout: Brepols.

Clunies Ross, Margaret; Gade, Kari Ellen; Marold, Edith; Nordal, Guðrún; Whaley, Diana; Wills, Tarrin 2012. General Introduction. In: Whaley, Diana (ed.) 2012. Poetry from the Kings' Sagas I: From Mythical Times to c. 1035 (2 vols.). Turnhout: Brepols, xiii-xciii.

Coleman, R. G. G. 1999. Poetic Diction, Poetic Discourse and the Poetic Register. In: Adams, James Noel; Mayer, Roland (eds.), Aspects of the Language of Latin Poetry. New York: Oxford University Press, 21-93.

Drout, Michael D. 2011. Variation within Limits: An Evolutionary Approach to the Structure and Dynamics of the Multiform. In: Oral Tradition 26(2), 447-474.

Egilsson, Sveinbjörn; Jónsson, Finnur 1931. Lexicon poeticum antiquæe linguæe septentrionalis. Ordbog over det norsk-islandske skjaldesprog. $2^{\text {nd }}$ edn. København: S. I. Møllers.

Faulkes, Anthony (ed.) 1999. Snorri Sturluson, Edda: Háttatal. London: Viking Society for Northern Research.

Foley, John Miles 1988. The Theory of Oral Composition: History and Methodology. Bloomington: Indiana University Press.

Foley, John Miles 1991. Immanent Art: From Structure to Meaning in Traditional Oral Epic. Bloomington: Indiana University Press.

Foley, John Miles 1993 [1990]. Traditional Oral Epic: The Odyssey, Beowulf, and the Serbo-Croatian Return Song. Berkeley, Los Angeles and Oxford: University of California Press.

Foley, John Miles 1995. The Singer of Tales in Performance. Bloomington: Indiana University Press.

Foley, John Miles 1996. Guslar and Aoidos: Traditional Register in South Slavic and Homeric Epic. In: Transactions of the American Philological Association 126, 11-41. 
Foley, John Miles 1999. Homer's Traditional Art. University Park: Pennsylvania University Press.

Foley, John Miles; Ramey, Peter 2011. Oral Theory and Medieval Studies. In: Reichl, Karl (ed.), Medieval Oral Literature. Berlin: de Gruyter, 71-102.

Fox, James J. 1977. Roman Jakobson and the Comparative Study of Parallelism. In: Armstrong, Daniel; van Schooneveld, C. H., Roman Jakobson: Echoes of His Scholarship. Lisse: Peter de Ridder Press, 59-90.

Frog 2009. Speech-Acts in Skaldic Verse: Genre, Formula and Improvisation. In: Dewey, Tonya Kim; Frog (eds.), Versatility in Versification: Multidisciplinary Approaches to Metrics. Berkeley Insights in Linguistics and Semiotics 74. New York: Peter Lang, 223-246.

Frog 2010. Multiformit kalevalamittaisessa epiikassa. In: Knuuttila, Seppo; Piela, Ulla; Tarkka, Lotte (eds.), Kalevalamittaisen runon tulkintoja. Helsinki: Suomen Kirjallisuuden Seura, 91-113.

Frog 2011. Multiforms and Meaning: Playing with Referentiality in Kalevalaic Epic. In: Huttu-Hiltunen, Pekka, et al. (eds.), Laulu kulttuurisena kommunikaationa. Kuhmo: Juminkeko, 49-63.

Frog 2012. On the Case of Vambarljóð I: Comments on Formulaicity in the sagnakvæðði. In: RMN Newsletter 5, 22-38.

Frog 2014a. Mythological Names in dróttkvoett Formulae I: When is a Valkyrie Like a Spear? In: Studia Metrica et Poetica 1(1), 100-139.

Frog 2014b. A Preface to Parallelism. In Frog (ed.), Parallelism in Verbal Art and Performance: Pre-Print Papers of Pre-Print Papers of the Seminar-Workshop, $26^{\text {th }}-27^{\text {th }}$ May 2014. Folkloristiikan toimite 21. Helsinki: Folklore Studies, University of Helsinki, 7-28.

Frog forthcoming. Metrical Entanglement and dróttkveett Composition: A Pilot Study on Battle-Kennings. In: Árnason, Kristján; Aðalsteinsson, Ragnar Ingi; Eypórsson, Pórhallur; Carey, Stephen Mark (eds.), Approaches to Germanic Metre [working title]. Reykjavík: University of Iceland Press.

Frog; Stepanova, Eila 2011. Alliteration in (Balto-)Finnic Languages. In: Roper, Jonathan (ed.), Alliteration in Culture. Houndmills: Palgrave MacMillan, 195-218.

Gade, Kari Ellen 1995. The Structure of Old Norse dróttkvætt Poetry. Ithaca: Cornell University Press.

Gade, Kari Ellen (ed.) 2009. Poetry from the Kings' Sagas II: From c.1035 to c.1300 (2 vols.). Skaldic Poetry of the Scandinavian Middle Ages 2. Turnhout: Brepols. 
Goldberg, Adele 2006. Constructions at Work: The Nature of Generalization in Language. Oxford: Oxford University Press.

Hainsworth, John Bryan 1968. The Flexibility of the Homeric Formula. Oxford: Clarendon Press.

Halliday, Michael A. K. 1978. Language as Social Semiotic: The Social Interpretation of Language and Meaning. London: Edward Arnold.

Harvilahti, Lauri 2000. Variation and Memory. In: Honko, Lauri, Thick Corpus, Organic Variation and Textuality in Oral Tradition. Studia Fennica Folkloristica 7. Helsinki: Finnish Literature Society, 57-75.

Hasan, Ruqaiya 1989. Linguistics, Language, and Verbal Art. Oxford: Oxford University Press.

Hollmérus, Ragnar 1992. Studier över allitterationen i Eddan. Helsinki: Svenska litteratursällskapet i Finland.

Honko, Lauri; Honko, Anneli 1995. Multiforms in Epic Composition. In: XI ${ }^{\text {th }}$ Congress of the International Society for Folk-Narrative Research (ISFNR), January 6-12, 1995, Mysore, India. Papers. Mysore: Central Institute of Indian Languages, II, 207-240.

Honko, Lauri; Honko, Anneli 1998. Multiforms in Epic Composition. In: Honko, Lauri; Handoo, Jawaharlal; Foley, John Miles, The Epic: Oral and Written. Mysore: Central Institute of Indian Languages, 31-79.

Honko, Lauri 1995. Multiformit ja pitkän eepoksen arvoitus. In: Sananjalka 37, 117-145.

Honko, Lauri 1998. Textualizing the Siri Epic. FF Communications 264. Helsinki: Academia Scientiarum Fennica.

Honko, Lauri 2003. The Maiden's Death Song and The Great Wedding: Anne Vabarna's Oral Twin Epic Written down by A.O. Väisnen. Helsinki: Academia Scientiarum Fennica.

Hopkins, Joseph 2014. Goddesses Unknown II: Ilmr. In: RMN Newsletter 8, 32-38.

Jakobson, Roman 1987 [1956]. Two Aspects of Language and Two Types of Aphasic Disturbances. In: Jakobson, Roman, Language in Literature, Pomorska, Krystyna; Rudy, Stephen (eds.). Cambridge: Harvard University Press, 95-114.

Jónsson, Finnur (ed.) 1967. Den Norsk-Islandske Skjaldedigtning A-B. København: Rosenkilde \& Bagger.

Kuhn, Hans 1983. Das Dróttkvoett. Heidelberg: Carl Winter. 
Lord, Albert Bates 1960. The Singer of Tales. Harvard Studies in Comparative Literature 24. Cambridge: Harvard University Press.

Marold, Edith 1983. Kenningkunst: Ein Beitrag zu einer Poetik der Skaldendichtung. Quellen und Forschungen zur Sprach- und Kulturgeschichte der germanischen Völker, Neue Folge 80. Berlin: de Gruyter.

Meissner, Rudolf 1921. Die Kenningar der Skalden: Ein Beitrag zur skaldischen Poetik. Bonn: Schroeder

Parry, Milman 1928. Lépithète traditionnelle dans Homère. Paris: Société d'Éditions Les Belles Lettres.

Price, Neil S. 2002. The Viking Way: Religion and War in Late Iron Age Scandinavia. Uppsala: Department of Archaeology and Ancient History.

Roper, Jonathan 2012. Synonymy and Rank in Alliterative Poetry. In: Sign Systems Studies 40(1/2), 82-93.

Saussure, Ferdinand de 1967 [1916]. Cours de linguistique générale. Paris: Éditions Payot \& Rivages.

Siikala, Anna-Leena 1990 [1984]. Interpreting Oral Narrative. FF Communications 245. Helsinki: Academia Scientiarum Fennica.

Skaldic Database. URL: http://abdn.ac.uk/skaldic/db.php

Tolley, Clive 1996. Vorðr and Gandr: Helping Spirits in Norse Magic. In: Arkiv för Nordisk Filologi 110, 57-75.

Wills, Tarrin 2009. The Development of Skaldic Language. In: Ney, Agneta; Williams, Henrik; Ljungqvist, Fredrik Charpentier (eds.), Á austrvega: Saga and East Scandinavia. Preprint Papers of the $14^{\text {th }}$ International Saga Conference, Uppsala, $9^{\text {th }}-15^{\text {th }}$ August 2009. Gävle: University of Gävle, 1032-1038.

Wray, Alison 2008. Formulaic Language: Pushing the Boundaries. Oxford: Oxford University Press.

Wray, Alison 2009. Identifying Formulaic Language: Persistent Challenges and New Opportunities. In: Corrigan, Roberta, et al. (eds.), Formulaic Language I-II. Typological Studies in Language 82-83. Amsterdam: John Benjamins Publishing, I, 27-51. 